\title{
Pollens, climate and allergies: Quebec initiatives
}

\author{
Isabelle Demers, MEnv (1); Pierre Gosselin, MD (2)
}

Tweet this article

\begin{abstract}
Pollen allergies are a major source of seasonal allergic rhinitis in North America. This type of rhinitis affects $17 \%$ of adults in Quebec, a marked increase in the last 30 years. Ragweed (Ambrosia artemisiifolia L.) pollens are responsible for $50 \%$ to $90 \%$ of rhinitis cases. Climate change has played a significant role in the increased prevalence of seasonal allergic rhinitis over the last few decades. In 2015, the Quebec government put in place a strategy to tackle this problem, the Stratégie québécoise de réduction de l'herbe à poux et des autres pollens allergènes [Quebec strategy to reduce ragweed and other allergenic pollens]. Based on solid evidence, the Strategy advocates for co-operation between stakeholders and the integration of control measures into the maintenance practices of municipalities and other large public and private landowners. This article presents the scientific data underpinning the Strategy and initial successes of the action taken under the Strategy.
\end{abstract}

Keywords: rhinitis, allergic, seasonal, allergen, Ambrosia, climate change, ragweed, pollen, public policy, prevention and control

\section{Introduction}

Among the various species of allergenic pollens, ragweed (Ambrosia artemisiifolia L.) pollen has been a great source of concern in the Quebec public health care system for more than 30 years. It is a major cause of seasonal allergic rhinitis in North America $^{1-3}$ and is believed to be responsible for $50 \%$ to $90 \%$ of pollen allergies, ${ }^{4}$ affecting approximately 1 in 10 Quebecers. ${ }^{5}$ In 2005, the health costs attributed to ragweed were evaluated at between $\$ 156.5$ million and $\$ 240$ million. ${ }^{6}$ In a context where the prevalence of allergic rhinitis has been rising constantly for 20 years in conjunction with the climate change being experienced worldwide, it has recently appeared necessary to enhance environmental control efforts to reduce the effects of allergenic pollens. That is why the Stratégie québécoise de réduction de l'herbe à poux et des autres pollens allergènes (SQRPA), launched in 2015 by the Quebec Department of Health and Social Services (MSSS), was put in place. ${ }^{7}$ Below are the scientific bases and main elements of the SQRPA to reduce ragweed and other allergenic pollens.

\section{Methodology and results}

The development of the SQRPA was informed by a narrative review of the scientific literature ${ }^{8}$ that was carried out in 2011 and resulted in 142 articles. The scientific literature was searched by means of various databases (PubMed, CSA Illumina, EBSCOhost, OvidSP, etc.). Those searches were supplemented with grey literature searches to gather study reports on the topic. The SQRPA has resulted in the funding and completion of several applied field research projects in Quebec, the main aspects of which are presented below.

\section{The impact of climate change}

To explain the increased prevalence of seasonal allergic rhinitis, a number of studies have highlighted the impact of climate

\section{Highlights}

- Climate change increases the quantities and allergenic potential of ragweed pollen.

- Seasonal allergic rhinitis caused by these pollens has increased significantly in North America.

- Simple environmental control methods can clinically decrease the impact of ragweed pollen.

- A coordinated policy that incorporates these control measures in municipalities' groundskeeping practices is being implemented in Quebec.

change. ${ }^{9-12}$ The combination of warmer temperatures and higher concentrations of $\mathrm{CO}_{2}$ is stimulating the growth and pollen production of allergenic plants. ${ }^{11,13}$ Specifically, an increase in the length of plants' pollen seasons has been observed, ${ }^{2}$ which is leading to increased human exposure to aeroallergens and therefore a higher rate of allergic sensitization.

In addition, studies tend to demonstrate shifts in the distribution of plants. New areas further to the north are becoming conducive to the establishment of certain species, with the result that human populations are being exposed to new allergens. ${ }^{14}$ The problem of pollen allergies was included under the health component of Quebec's climate change action plan (Plan d'action contre les changements climatiques du Québec) in 2007.

\section{Data obtained from applied research}

In Quebec, knowledge of ragweed management has increased enormously over

\section{Author references:}

1. Ministère de la santé et des services sociaux du Québec, Québec, Quebec, Canada

2. Institut national de santé publique du Québec and Ouranos, Québec, Quebec, Canada

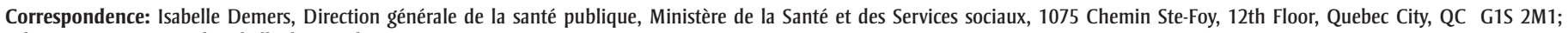
Tel: 418-266-6717; Email: isabelle.demers.dgsp@msss.gouv.qc.ca 
the last 10 years. ${ }^{15-19}$ The acquisition of solid evidence demonstrating the positive impact of pollen control has strengthened the relevance of managing the plant at the municipal level.

The Herbe à poux 2007-2010 research project demonstrated that it is entirely possible to effectively manage ragweed across a municipality at low cost while having a real impact on the health of the allergic population. ${ }^{16,20}$ Concretely, the project involved engaging different key players in seven targeted activity sectors in the community (agricultural, business, industrial, institutional, municipal and residential sectors, as well as transportation routes) to synchronize their ragweed control actions. ${ }^{20}$ The players showed a strong preference for mowing, with $60 \%$ of the players practising it. ${ }^{21}$ To determine whether the strategies deployed were effective, two approaches were taken. Pollen concentrations and the density of ragweed were measured using a semiexperimental pre-test/post-test design with a non-equivalent comparison group. In addition, the health impacts on allergic people were assessed using a quasi-experimental chronological series design with a non-equivalent comparison group. At the end of the project, a decrease in ragweed pollen concentrations was observed in the experimental environment compared with the control environment, a statistically and clinically significant reduction in the intensity of certain symptoms was measured in one in two allergic individuals living in the experimental environment, and there was an improvement in their quality of life. ${ }^{16,20}$ The preferred intervention method during this project, coordinated management, was deemed very efficient from an economic viewpoint compared with the minimal intervention method generally applied in the province. $^{20,22}$ Concretely, coordinated management consists of engaging various key players in the community (e.g. municipality, provincial department of transportation and other large owners and managers of private or public land) to implement joint and simultaneous action for controlling ragweed. In comparison, minimal intervention consisted of regular groundskeeping, without focusing on ragweed in particular and without engaging the community.

In 2008, a study was conducted on the links between the degree of local ragweed infestation and the prevalence of allergic reactions among children 6 months to 12 years old living on the Island of Montreal. ${ }^{17}$ The study shows a statistically significant positive relationship between the risk of allergic reactions and the level of local exposure to ragweed (influence zone of 300 to $1000 \mathrm{~m}$ ). The study therefore demonstrates the relevance of local action to control ragweed to reduce the frequency of allergies in the population, in the context of adaptation to climate change.

Another project carried out in Montreal involved evaluating a ragweed pollen control approach through the distribution of personalized information to the managers of ragweed-infested sites. It explained the health impacts associated with ragweed and asked that the lands be mowed twice during the summer. ${ }^{19}$ The results suggest that landowners, particularly owners of vacant lots, are more likely to control ragweed on their land when they receive several notices and reminders. Three times as many owners mowed the ragweed on their land after receiving four notices compared with those who received only one notice.

In response to the need to monitor the presence of ragweed in Quebec and its territorial extension in the future, a method to predict the probability of the presence of ragweed involving remote sensing has been developed. ${ }^{23}$ The first phase of the project, carried out between 2011 and 2013 , resulted in a prediction rate of $60 \%$ to $80 \%$ (depending on the region). The second phase of the project is currently under way and is aimed at improving the method's effectiveness so it can be more widely used in the future, providing useful information to municipalities to help them enhance their climate change adaptation strategies.

Work done by Agriculture and Agri-Food Canada has proved the effectiveness of mowing, which is the control method most widely used by Quebec municipalities. ${ }^{15}$ In that study, conducted in a greenhouse, plants that reached $25 \mathrm{~cm}$ in height were mowed to a height of $10 \mathrm{~cm}$ just before flowering, around mid-July; they were mowed a second time when the regrowth reached $25 \mathrm{~cm}$ again, around mid-August (see Figure 1).

Lastly, a study conducted by the climate change research consortium Ouranos evaluated the costs arising from the impacts of climate change on health. That study revealed that, for the period from 2015 to 2065, the portion of the costs of ragweed allergies attributable solely to climate change impacts are nearly $\$ 360$ million for the government and $\$ 475$ million for society. ${ }^{24}$ Those amounts are in addition to the basic costs of ragweed allergies, which do not take into account the impact of climate change and are estimated at $\$ 3.4$ billion for the same period. ${ }^{24}$ Any adaptation efforts will therefore lessen the impacts of the problem of pollen allergies and reduce the costs to the government and society.

\section{Ragweed management and control}

Most ragweed pollen is deposited close to its source, within a radius of $1 \mathrm{~km} .^{17,25}$ Municipal agencies are in the best position to act because of their roles and responsibilities. Municipalities manage $50 \%$ of the Quebec road network (approximately $92,000 \mathrm{~km}$ of roads and streets, where ragweed flourishes in their rightsof-way). ${ }^{26}$ They also manage several sites that are conducive to the establishment of ragweed (snow dumps, recreational fields, vacant lots, etc.) and can regulate nuisances. These governments also have detailed knowledge of the territory, can influence their local partners and have the necessary equipment to maintain the lands in question, which makes them indispensable. Municipalities therefore play an essential role in ragweed management and control and in its increasing presence in the context of climate change.

\section{Control methods}

Various methods can be used to control ragweed. Generally speaking, there are two broad categories:27,28 methods that prevent the spread of ragweed (hardscaping, planting a competitive plant cover, etc.) and methods that control the ragweed already present (hand pulling, mowing, application of low-impact herbicides, etc.).

Preventive methods are more effective than the other methods in controlling ragweed, as preventive methods impede it from establishing itself in an area. However, they require rigorous maintenance and are expensive. ${ }^{27,29}$ Among the methods aimed at completely or partially destroying the plant, hand pulling is an excellent method to use on small plots of 

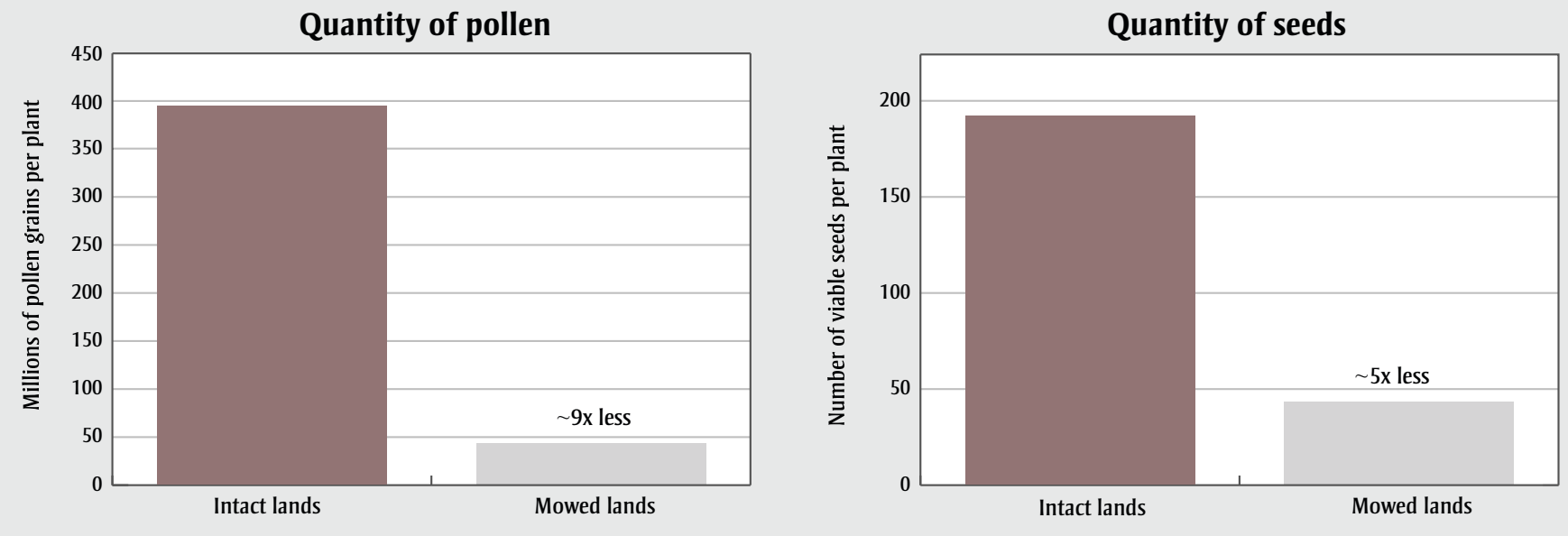

Source: Adapted from Simard and Benoît, 2011. ${ }^{15}$

land, but it is inappropriate for large areas. $^{27,29}$ Heat methods (boiling water or steam) are somewhat attractive, but their application puts other nearby plants at risk, and they are costly. ${ }^{27,29}$ It is an appropriate technique for combatting ragweed growing in the cracks between asphalt and cement along streets. ${ }^{29}$ The mechanical method, which involves using the stiff metal brushes on municipal sweepers, is a good alternative to the heat method, because it can be very effective in difficult-to-reach spots (e.g. on sidewalk edges), but uses machinery that is normally used for cleaning. ${ }^{8}$ Lastly, applying low-environmental-impact herbicides (saline solution) is an effective option in areas with a high density of plants; however, it is expensive, because it requires specialized equipment, qualified employees and rigorous monitoring. ${ }^{27,30}$ Mowing is a simple, effective and low-cost control method, ${ }^{20,27,30}$ particularly when it is carried out at a specific stage in the development of ragweed. ${ }^{15}$

\section{Discussion}

Quebec's Strategy was put in place in 2015. It is governed by an interdepartmental steering committee chaired by the MSSS. A representative of the Société québécoise des infrastructures, the organization that manages the real estate portfolio of Quebec public departments and agencies, also sits on the steering committee.

Drawing on solid research evidence, the SQRPA relies on coordination between various stakeholders and is aimed at promoting the integration of allergenic pollen control measures into the routine maintenance practices of Quebec government municipalities, departments and agencies. In a changing climate, it is essential to adapt policies and intervention methods to better control allergenic pollens. That is why the SQRPA has been integrated into the adaptation component of Quebec's climate change action plan, the Plan d'action 2013-2020 sur les changements climatiques du Québec (PACC 2013-2020). The ultimate objective of this initiative is to reduce the health effects associated with allergenic pollens and improve the quality of life for people who have a ragweed allergy.

\section{The SQRPA includes several elements:}

- A financial assistance program to encourage municipalities to implement allergenic pollen control measures in their jurisdictions; 15 municipalities participated over two years;

- The evaluation of the interventions funded by the SQRPA through the measurement of pollen concentrations before and after the interventions;

- A management and control guide for ragweed and other allergenic pollens; ${ }^{27}$

- A maintenance guide for institutional land owned by government departments and agencies; and

- A partnership with the Association pulmonaire du Québec [Quebec lung association] to promote the organization's annual campaign to encourage Quebec municipalities to remove ragweed plants.

Figure 2 presents an example of the initial results obtained from Granby, one of the municipalities that received funding through the SQRPA. Pollen concentrations were measured at two sites: a control site, where no ragweed control was carried out; and a site where ragweed control measures were carried out.

\section{Strengths and weaknesses}

To our knowledge, the SQRPA is a very innovative approach around the world, and its hands-on approach and effectiveness make it very affordable for governments. Expectations as to the assessment of the SQRPA's long-term effectiveness must remain modest, since the Strategy is only starting to be implemented and a number of Quebec municipalities do not have the resources required to put concerted actions in place to control allergenic pollens. Recruiting municipalities to join the program could prove more difficult going forward and may not be sustainable over time, given that the budgets allocated to municipalities are not recurrent and there is uncertainty around funding for the SQRPA beyond 2020. Other health priorities may affect municipal decisions. However, the strong growth of these allergies should guarantee citizens' support for this engagement to achieve better environmental control if awareness efforts are maintained. The necessity to maintain these awareness efforts is the 
FIGURE 2

Effect of ragweed control measures on pollen concentration in Granby, QC, in 2016

Total pollen concentrations

July 25 to September 16, 2016

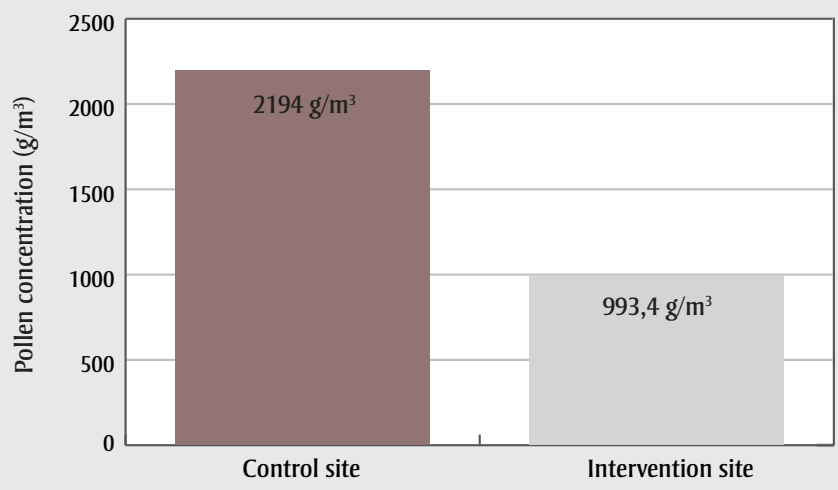

Source: Adapted from Association pulmonaire du Québec, $2016 .^{3}$

same for all climate change adaptation actions, thus this strategy aims to facilitate decision making for managers at the municipal level by providing a favourable context for implementing the SQRPA and encouraging a continued popular demand among elected officials, which often change during elections. ${ }^{32}$

\section{Conclusion}

The implementation of the SQRPA is an innovative initiative to control allergenic pollens. In view of the significant increase in respiratory allergies attributable to pollens that has been observed in the last few decades and the growing importance being paid to them, the SQRPA's implementation is important and meets the needs expressed by the health care system and municipalities for a number of years. In addition, with climate change currently occurring, worsening of the problem of pollen allergies is to be expected in the coming decades. The implementation of this climate change adaptation measure will therefore help reduce health impacts and costs for the government and society. If control measures are applied appropriately, the control of allergenic pollens will lead to lower pollen concentrations in the air and, therefore, reduced exposure of people with seasonal allergic rhinitis, which will lead in turn to decreases in the severity of symptoms experienced by those individuals and thus improvements in their quality of life.

However, implementing such a program requires a firm and concrete commitment from provincial and local government decision-makers. Communication is also a crucial factor, particularly with the target clientele: municipalities. The initiative must therefore rely on the existence of direct communication channels with these organizations. Although the SQRPA has led to the implementation of innovative projects that have proved successful, few municipalities are still prioritizing such projects, despite a real willingness to reduce the health effects of allergenic pollens. It is therefore crucial to continue and increase awareness efforts to convince decision-makers to tackle this problem and allocate the necessary resources to it, to strengthen climate change adaptation in Quebec.

\section{Acknowledgements}

Funding for this strategy was provided by the Government of Quebec's Fonds vert.

\section{Conflicts of interest}

The authors declare no conflicts of interest.

\section{Authors' contributions and statement}

Both authors contributed to all stages of writing this article and read and approved the final version. ID was the person responsible for setting up the strategy described, and she was responsible for some of the data collected.

The content and views expressed in this article are those of the authors and do not necessarily reflect those of the Government of Canada and the involved stakeholders.

\section{References}

1. Ihler F, Canis M. Ragweed-induced allergic rhino-conjunctivitis: Current and emerging treatment options. J Asthma Allergy. 2015;8:15-24.

2. Ziska LH, Knowlton K, Rogers C, et al. Recent warming by latitude associated with increased length of ragweed pollen season in central North America. Proceedings of the National Academy of Sciences. 2011; 108(10):4248-51

3. Bielory L, Lyons $\mathrm{K}$, Goldberg R. Climate change and allergic disease. Current Allergy and Asthma Reports. 2012;12(6):485-94.

4. Comtois P, Gagnon L. Concentration pollinique et fréquence des symptômes de pollinose: une méthode pour déterminer les seuils cliniques. Revue française d'Allergologie et d'Immunologie Clinique. 1988;28(4): 279-86.

5. Canuel M, Lebel G. Prévalence des symptômes et du diagnostic de la rhinite allergique chez les 15 ans et plus au Québec, 2008. Québec, QC: Institut national de santé publique du Québec; 2012. Available from: https:// www.inspq.qc.ca/pdf/publications /1447_PrevalenceSymptDiagnos RhiniteAllerg15AnsEtPlusQc_2008.pdf

6. Tardif I. Portrait des coûts de santé associés à l'allergie au pollen de l'herbe à poux, année 2005. Longueuil, QC: Agence de la santé et des services sociaux de la Montérégie; 2008. Available from: http://extranet.sante monteregie.qc.ca/depot/document /2516/NUISANCE-POUX-Coutssante -2005.pdf

7. Ministère de la Santé et des services sociaux du Québec (MSSS). Herbe à poux et autres pollens allergènes. Stratégie québécoise de réduction de l'herbe à poux et des autres pollens allergènes (SQRPA) [Internet]. Québec, QC: MSSS; 2018 [updated August 20, 2018]. Available at: http://www.msss .gouv.qc.ca/professionnels/sante -environnementale/pollens/strategie -quebecoise-de-reduction-de-l-herbe-a -poux-et-des-autres-pollens-allergenes -sqrpa/ 
8. Demers I. État des connaissances sur le pollen et les allergies. Les assises pour une gestion efficace. Québec, QC: Institut national de santé publique du Québec; 2013. Available from: https://www.ins pq.qc.ca/pdf /publications/1678_EtatConnPollen Allergies_AssisesGestionEfficicace.pdf

9. D’Amato G, Holgate ST, Pawankar R, et al. Meteorological conditions, climate change, new emerging factors, and asthma and related allergic disorders. A statement of the World Allergy Organization. World Allergy Organization Journal. 2015;8(1):1-52.

10. Weber RW. Impact of climate change on aeroallergens. Annals of Allergy, Asthma \& Immunology. 2012;108(5): 294-9.

11. United States Environmental Protection Agency (US EPA). Review of the impacts of climate variability and change on aeroallergens and their associated effects (Final Report) [Internet]. Washington, DC: US EPA; 2008 Available from: https://cfpub.epa.gov /ncea/risk/recordisplay.cfm?deid $=190306$

12. Beggs PJ. Impacts of climate change on aeroallergens: Past and future. Clinical and Experimental Allergy: Journal of the British Society for Allergy and Clinical Immunology. 2004;34(10):1507-13.

13. Crimmins A, Balbus J, Gamble JL, et al. The impacts of climate change on human health in the United States: a scientific assessment. Washington, DC: U.S. Global Change Research Program (USGCRP); 2016. 312 p.

14. Beggs PJ. Adaptation to impacts of climate change on aeroallergens and allergic respiratory diseases. International Journal of Environmental Research and Public Health. 2010; 7(8):3006-21.

15. Simard M-J, Benoît D-L. Effect of repetitive mowing on common ragweed (Ambrosia artemisiifolia L.) pollen and seed production. Annals of Agricultural and Environmental Medicine. 2011;18(1):55-62.
16. Direction de la Santé publique de la Montérégie. Projet herbe à poux 2007-2010. Résumé scientifique phase 1 [Internet]. Québec, QC : Ministère de la Santé et des Services sociaux du Québec; 2012. Available from: http://publications.msss.gouv .qc.ca/acrobat/f/documentation /2011/11-244-03W.pdf

17. Jacques L, Goudreau S, Plante C, et al. Prévalence des manifestations allergiques associées à l'herbe à poux chez les enfants de l'île de Montréal 2008. Québec, QC: Institut national de santé publique du Québec; 2010. Available from: https://www.inspq .qc.ca/en/node/1038

18. Joly M, Bertrand P, Gbangou RY, et al. Paving the way for invasive species: road type and the spread of common ragweed (Ambrosia artemisiifolia). Environmental Management. 2011;48(3):514-22.

19. Plante C, Smargiassi A, Hubert F, et al. Implementation and evaluation of a communication strategy to control ragweed pollen. Environment and Pollution. 2016;5(1):87-91.

20. Direction de la Santé publique de la Montérégie. Mobiliser une communauté du sud du Québec pour contrer l'herbe à poux : analyse des coûts de l'intervention et de ses effets sur la distribution spatiale des plants, du pollen et des symptômes d'allergie chez des adultes. Québec, QC: Institut national de santé publique du Québec; 2013.

21. Direction de santé publique de Montérégie. Projet Herbe à poux 2007-2010. Réduire le pollen de l'herbe à poux : mission réaliste. Le succès d'une communauté mobilisée [Internet]. Québec, QC : Ministère de la Santé et des services sociaux du Québec; 2011. Available from: http:// publications.msss.gouv.qc.ca/msss /fichiers/2011/11-244-02.pdf

22. Beauchemin C, Drapeau J-B, Groulx $J$, et al. Évaluation économique d'un mode d'interventions concerté dans la lutte contre l'herbe à poux au Québec. Montreal, QC: Université de Montréal; 2013.
23. Ngom R, Gosselin P. Development of a remote sensing-based method to map likelihood of common ragweed (Ambrosia artemisiifolia) presence in urban areas. IEEE Journal of Selected Topics in Applied Earth Observations and Remote Sensing. 2014;7(1):126-39.

24. Larrivée C, Sinclair-Desgagné N, Da Silva L, et al. Évaluation des impacts des changements climatiques et de leurs coûts pour le Québec et l'État québécois. Rapport d'étude 2015-243. Montréal, QC: Ouranos; 2015. Available from: http://www.environnement .gouv.qc.ca/changementsclimatiques /evatuation-impacts-cc-couts-qc-etat .pdf

25. Raynor GS, Ogden EC, Hayes JV. Dispersion and deposition of ragweed pollen from experimental sources. Journal of Applied Meteorology. 1970;9(December 1970):885-95.

26. Transports Québec. Information sur le réseau routier [2017-10-19]. Montréal, QC: Transports Québec; [cited 2019 Jan 8]. Available at: https://www .transports.gouv.qc.ca/fr/projets -infrastructures/info-reseau-routier /Pages/information-sur-le-reseau -routier.aspx

27. Demers I. Guide de gestion et de contrôle de l'herbe à poux et des autres pollens allergènes. Québec, QC: Ministère de la Santé et des Services sociaux du Québec; 2015. Available from: http://publications .msss.gouv.qc.ca/msss/fichiers /2018/18-244-05W.pdf

28. Table québécoise sur l'herbe à poux (TQHP). Dossier herbe à poux : fiches d'aide à la décision. Montréal, QC: Régie régionale de la santé et des services sociaux de la Montérégie, Direction de la santé publique; 2002.

29. Massicotte R, Beaumont J-P, HamelFortin S, et al. Implanter un couvert végétal. Document d'information sur la technique d'implantation d'un couvert végétal compétitif afin de lutter contre l'herbe à poux (Ambrosia artemisiifolia L.). Longueuil, QC: Agence de la santé et des services sociaux de Montérégie, Groupe de travail sur le couvert végétal compétitif (GTCVC) de Table québécoise sur l'herbe à poux; 2006. 
30. Genivar. Maîtrise de l'herbe à poux. Comparaison de méthodes d'intervention. Montréal, QC: Hydro Québec; 2011.

31. Association pulmonaire du Québec. Rapport des résultats de l'échantillonnage des pollens dans le cadre du programme de financement de la Stratégie québécoise de réduction de l'herbe à poux et des autres pollens allergènes. Montréal, QC: Association pulmonaire du Québec; 2016.

32. Mehiriz K, Gosselin P. Municipalities' preparedness for weather hazards and response to weather warnings. PLoS ONE. 2016;11(9):e0163390. doi: 10.1371/journal.pone.0163390. 